\title{
Vulvar Large Cell Neuroendocrine
}

\section{Carcinoma}

National Cancer Institute

\section{Source}

National Cancer Institute. Vulvar Large Cell Neuroendocrine Carcinoma. NCI Thesaurus.

Code C128245.

A high grade neuroendocrine carcinoma that arises from the vulva. It is characterized by the presence of malignant large cells with neuroendocrine differentiation. 